\title{
Expanding Nordic Literacy Research
}

\author{
Marte Blikstad-Balas ${ }^{1 \star}$, Michael Tengberg ${ }^{2}$, Gustaf B. U. Skar ${ }^{3}$ \\ and Arild M. Bakken ${ }^{4}$ \\ ${ }^{1}$ University of Oslo $;{ }^{2}$ Karlstad University; ${ }^{3}$ Norwegian University of Science and technology; \\ ${ }^{4}$ University of Stavanger
}

Literacy is a relatively recent phenomenon in the history of mankind, but has become somewhat of a constant in human life. Literacy skills, in its broadest sense, is a prerequisite to participate in most societal, vocational and social settings. Even in occupations not traditionally associated with reading and writing, researchers have documented that substantial literacy requirements are embedded in everyday tasks and activities (Beaufort, 2008; Joly, 2010; Karlsson, 2009; Mikulecky, 1998; Smagorinsky \& Mayer, 2014). We consume and produce more texts than ever before, and in more areas of our lives than ever before ( e.g Brockmeier \& Olson, 2009; Kwok et al., 2016). Literacy is local and global at the same time (Rowsell \& Pahl, 2015). It concerns us both through the myriad of literacy practices we take part in, but also because written communication is the basic infrastructure not only for communication between all organisations and communities that constitute our society at a broader level, but also for knowledge acquisition and democratic participation.

Because literacy is everywhere - from the e-mails and messages currently craving your attention as you read this (written!) Editorial, the results of your childs' reading test, to the novel you may have on your night stand - it is also easy to take for granted or even underestimate the roles it has in human life. While there is general consensus that our access to each other and to society is mediated through texts in our everyday life - and more so now than for example one hundred or even fifty years ago, we still lack empirical analyses and rigorous descriptions of the increasingly textual communication literacy enables and maintains (Skaftun, Solheim \& Uppstad, 2015).

The study of how people engage with literacy also permeates all aspects of life, making the field of literacy studies a highly complex, multi-faceted, contested and highly political field. As a research field, literacy crosses "the domains of education, anthropology, literature, language, linguistics, psychology, sociology, cultural studies and everyday practice" (Rowsell \& Pahl 2015, p. 3). The question 'what is good

\footnotetext{
^Correspondence: Marte Blikstad-Balas, email: marte.blikstad-balas@ils.uio.no
} 


\section{Blikstad-Balas et al.}

science about literacy development and use?' is continuously being charged with new complexities as we expand both the notion of text and the notion of literacy itself and researchers from different disciplines may provide very diverging answers.

As should be expected of such a complex phenomenon, there are several ways to approach literacy theoretically and methodologically. It was stated in the very first Editorial of this journal that different research traditions within the field of literacy research will have both their focal points and their blind spots (Skaftun et al., 2015). That is why it is crucial to bring different perspectives together, and to adopt an integrative view of literacy where multiple theoretical and methodological approaches are appreciated and explored. An initial ambition of the journal, when established five years ago, was to publish "rich pictures" of literacy settings in the Nordic countries. The founding editors, Skaftun, Solheim and Uppstad (2015), explained how they wanted the Nordic Fournal of Literacy Research to be "a forum for the production of knowledge and scholarly reflection about literacy in people's lives - in and out of school - today, in the past, and in the potential future". Further, they stated that they had ambitions for the journals' publications to broaden and deepen our understanding of written language practices from different facets of our lives: "from the very first encounter with writing, over the almost fantastic event of breaking the code and understanding what the text says, to masterful participation in a textual culture".

As new editors, we humbly take over the editorial responsibilities of a journal that we appreciate so highly. We would like to officially thank the former editors Uppstad, Solheim and Skaftun, for the opportunity to keep pursuing the journals' bold ambitions. We believe the Nordic fournal of Literacy Research has become the go-to journal for those interested in the study and development of literacy in the Nordic context. This is quite an accomplishment for a journal that has only been around for five years, and it says something about the quality of the work done by the first Editorial team, and also something about the fact that the field really needs a journal devoted to the topic of literacy in the Nordic context. The journal's readership has increased steadily over the first five years, and so has the number of published articles and special issues.

Our ambition, as a new Editorial team, is to keep publishing high quality work focusing on literacy in and out of educational contexts. We have, however, challenged ourselves on how we could improve the journal even further - and we would like to take the opportunity of this first Editorial to make these ambitions explicit.

One thing we hope to contribute with is a continued focus on increasing the methodological and theoretical diversity of literacy research, and in particular more quantitative studies as well as more studies drawing on both quantitative and qualitative data. This should not replace the high quality case studies or more qualitative work, but should serve as an addition and even expansion to it. We believe it is important to have a broad perspective on literacy as a phenomenon, how it is taught and learned, and how it is embedded in everyday practices across educational contexts. In order 
to shed light on all aspects of literacy practice within education and outside, there is a need for even more methodological flexibility. In line with this, we will also encourage more hypothesis testing, large scale interventions, design-based research and systematic reviews. We will keep publishing new study protocols, and we also welcome more theoretical articles.

Another area we would like to cover to a larger degree than today, is the field of early literacy research. We would welcome, for example, studies related to young children's literacy practices in kindergarten, preschool and primary school. As the child's first encounter with alphabetic script and with the world of texts, these practices lay the foundations for their momentous rediscovery of the culture to which they belong. We believe it is important to shed more light on these practices, both in their own right and for the importance they have for literacy practices in later school years and beyond formal education.

It says in the name that the journal is Nordic, and the new Editorial team has ambitions to strengthen the Nordic perspective even further. In addition to the Norwegian, Swedish and Danish research already being published, we therefore welcome research particularly from Finland and Iceland. In addition, we would encourage Nordic literacy researchers who work together across the different countries to publish in the journal.

The Nordic Fournal of Literacy Research has developed into an important arena for disseminating literacy research from the Nordic countries. In keeping with the ambitions set in the inaugural editorial in 2015, the journal published articles with the potential to impact literacy instruction, policy-making, and-not least-further research. Access to literacy continues to be essential for an individual to participate in society actively, and as literacy researchers, we continuously have a major responsibility to explore literacy learning, development and instruction, as well as identity and motivational aspects of literacy. The Nordic Journal of Literacy research will also, in the future, be an essential outlet for such research.

Marte Blikstad-Balas

Gustaf B. Skar

Michael Tengberg

Arild Michel Bakken

\section{References}

Beaufort, A. (2008). Writing in the professions. In Bazerman, C. (Ed.), Handbook of research on writing: History, society, school, individual, text (pp. 221-235). Mahwah, NJ: Lawrence Erlbaum.

Brockmeier, J., \& Olson, D. (2009). The literacy episteme. From Innis to Derrida. In Olson, D. R., \& Torrance, N. (Eds.), Cambridge handbook of literacy (pp. 3-22). New York, NY: Cambridge University Press.

Joly, N. (2010). Tracing cows: Practical and administrative logics in tension? In Barton, D., Papen, U. (Eds.), The anthropology of writing: Understanding textually mediated worlds (pp. 90-105). London, UK: Continuum.

Karlsson, A.-M. (2009). Positioned by reading and writing literacy practices, roles, and genres in common occupations. Written Communication, 26(1), 53-76. 


\section{Blikstad-Balas et al.}

Kwok, M. N., Ganding, E., Hull, G. A., \& Moje, E. B. (2016). Sociocultural approaches to high school writing instruction. Examining the roles of context, positionality, and power. In MacArthur, C. A., Graham, S., Fitzgerald, J. (Eds.), Handbook of writing research (Vol. 2, pp. 257-271). New York, NY: Guilford.

Mikulecky, L. (1998). Adjusting school writing curricula to reflect expanded workplace writing. In Garay, M. S., Bernhardt, S. A. (Eds.), Expanding literacies: English teaching and the new workplace (pp. 201-223). Albany: State University of New York Press.

Rowsell, J., \& Pahl, K. (2015). Introduction. In J.Rowsell \& K. Pahl (Eds.), The Routledge handbook of literacy studies (pp. 1-16) Routledge.

Skaftun, A., Solheim, O. J., \& Uppstad, P. H. (2015) Towards an Integrated View of Literacy. Nordic fournal of Literacy Research, Vol. 1, pp. 1-3.

Smagorinsky, P., \& Mayer, R. E. (2014). Learning to be literate. In Sawyer, K. (Ed.), The Cambridge handbook of the learning sciences (pp. 605-625). Cambridge, UK: Cambridge University Press. 